\title{
Knowledge and practices about hantavirus pulmonary syndrome in a cluster of Japanese communities in Argentina
}

\author{
Kuniaki Suzuki ${ }^{1}$ and Luciano E. Mutinelli ${ }^{1}$
}

Suggested citation

Suzuki K, Mutinelli LE. Knowledge and practices about hantavirus pulmonary syndrome in a cluster of Japanese communities in Argentina. Rev Panam Salud Publica. 2009;25(2):128-33.

ABSTRACT Objectives. To provide information on hantavirus pulmonary syndrome (HPS) knowledge and practices among a cluster of the rural Japanese communities near La Plata in central Argentina, an area with confirmed HPS cases. Particular emphasis was placed on testing the hypothesis that there would be differences between household use of HPS prevention measures based on the head-of-household's knowledge of HPS.

Methods. A questionnaire was designed in three sections: (1) household demographic characteristics, (2) HPS knowledge, and (3) HPS preventive measures. Questionnaires were given to the household head or other adult representing the household at an HPS prevention seminar sponsored by the Japanese Association of La Plata in February 2007. Total HPS knowledge scores were dichotomized into high (equal to or more than the median knowledge score) and low (less than the median). Differences between the two household groups were categorized, according to the degree of HPS knowledge, and analyzed.

Results. The 86 households that responded accounted for about $72 \%$ of the total study households in the area. The median knowledge score of 5 (range: 0-9, of 10) divided the study households into two groups: high knowledge score group $(\mathrm{n}=40)$ and low knowledge score group $(\mathrm{n}=46)$. The findings suggest an association between a household's accurate HPS knowledge and its respective use of HPS preventive measures.

Conclusions. The findings of the study have important implications for taking further steps toward improved HPS management and prevention strategies.

Key words Hantavirus pulmonary syndrome, rodentia, ethnic group and health, Argentina.

Hantavirus pulmonary syndrome (HPS), a viral disease with a $40-60 \%$ mortality rate, is caused by the genus Hantavirus, family Bunyaviridae (1). It has a long-time association with its typical reservoir, the New World rodents of the family Muridae, subfamily Sigmo-

Facultad de Ciencias Veterinarias, Universidad Nacional de La Plata, Argentina. Send correspondence to: Kuniaki Suzuki, PROVETSUR, FCVUNLP, 60 y 118, CC296, La Plata, B1900AVW, Argentina; telephone/fax: +54 221425 3276; e-mail: pvs@provetsur.net dontinae. The reservoir host is usually asymptomatically infected. Transfer of the virus can occur when either a human enters the host's habitat or the host settles in the proximity of humans (2). People in contact with rodents or their excreta are at risk of hantavirus infection. Certain occupational groups, such as farmers, are at greater risk of infection and also exhibit higher hantavirus antibody prevalence than control groups. Certain activities, such as hand cultivating, woodcutting, reopening of unventilated rooms, and cleaning near infected rodent habitats, have been indicated as high-risk for HPS infection $(3,4)$.

In Argentina, the first cases of HPS were reported 1995 in the southwestern region. Since then, Argentina has been the South American country with the highest number of officially confirmed cases (5). Current cases are clustered in three geographically-separate areas, i.e., the north (Jujuy Province), the center (Buenos Aires Province-where the study communities are located) and in the southwest (Río Negro Province). The virus responsible for HPS cases in Ar- 
gentina, the Andes virus, was described in 1995 as a new kind of hantavirus, capable of person-to-person transmission $(6,7)$.

There are an estimated 100000 to 200000 cases of hantavirus infection worldwide per year (8). In Argentina, the total number of HPS cases from 19932004 was 592 (9). Public concern and fears are focused on rodents as the source of HPS. Especially those who work outdoors, such as farmers in hantavirusaffected areas, fear contracting and dying of the disease. Being a country of immigrants, Argentina has many firstgeneration citizens from foreign countries, such as Japan, that are especially concerned with obtaining precise information on HPS prevention, but are dealing with a language barrier (personal communication, Japanese Association, La Plata, 2007).

Although the results of actual condition surveys of medical staff, patients, and their families in relation to HPS have been publicized $(10,11)$, data focusing on population groups at high-risk for HPS infection are few (12). Researchers in Argentina have made positive efforts to further understanding of the molecular biology and epidemiology of hantaviruses and have discovered new ones, such as the Andes virus (13-18). On the other hand, additional research regarding the inhabitants of epidemiologically high-risk areas and those at risk due to their occupation is required to improve management and prevention strategies. Surveys of community-based knowledge, attitudes, behaviors, and practices (KABP) of a wide range of health issues, such as avian influenza, epilepsy, and HIV / AIDS, have been used successfully to gather information and develop systems and activities (19-21). However, there are no previous studies, as far as the authors know, on HPS knowledge and practices among any high-risk population groups in the world.

The objective of this study was to provide information on the knowledge and practices of HPS among a cluster of the rural Japanese communities in Argentina in which HPS cases have occurred in recent years. Particular emphasis was placed on testing the hypothesis that there must be differences between households relative to the degree of knowledge regarding HPS and the use of recommended preventive measures.

FIGURE 1. Map of La Plata, the capital city of the Buenos Aires Province. Inset: square indicates position of La Plata in Argentina (shaded) in South America

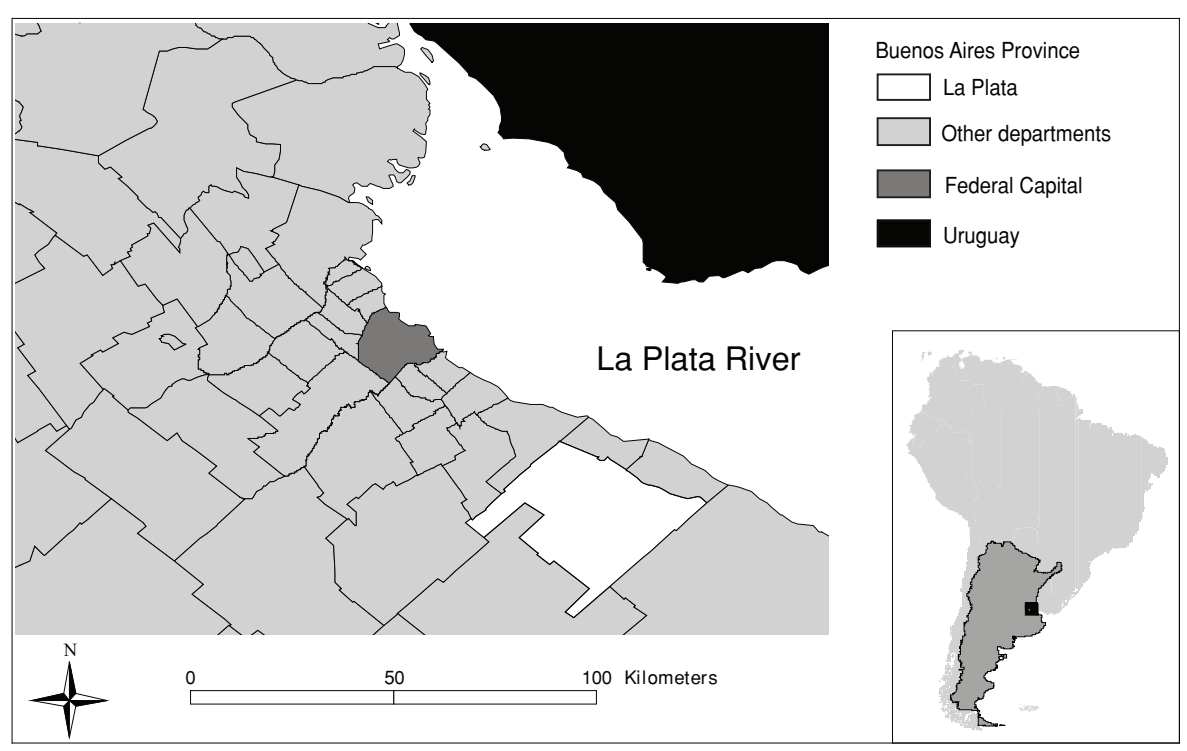

\section{MATERIALS AND METHODS}

\section{Study area}

La Plata is the capital of the Providence of Buenos Aires, located in the central part of Argentina ( $\left.34^{\circ} 55^{\prime} \mathrm{S}, 57^{\circ} 17^{\prime} \mathrm{W}\right)$. The city is about $60 \mathrm{~km}$ southeast of the federal capital, the city of Buenos Aires, and is a separate administrative entity (Figure 1). Most of the area is fertile plains at $10 \mathrm{~m}$ above sea level. The city has a temperate climate, with a mean annual temperature of $16^{\circ} \mathrm{C}$ and rainfall of $1000 \mathrm{~mm}$. The mean annual humidity is $78 \%$ and a prevailing wind blows from the southeast for four months a year. The total land area is about $940 \mathrm{~km}^{2}$. The population is estimated to be 600000 (22).

Of the 308 HPS cases registered in Argentina from 1998-2001, about 30\% occurred in the Buenos Aires Province (23). Of the 58 HPS cases registered in Buenos Aires Province from 1997 through the first quarter of 2000, more than $50 \%$ occurred in La Plata and its neighboring localities. The two lineages of Andes virus (AND Cent Buenos Aires and AND Cent Plata) causing HPS in the province, were found to co-circulate only in La Plata (24). In 2002, Buenos Aires Province recorded more than twice the usual number of HPS cases (52 vs. 20-25); 40 of these occurred in La Plata (25). Colonia Urquiza, home to the Japanese communities that were studied, lies in the suburbs of La
Plata. There are 120 Japanese households with approximately 500 Japanese residents, as well as an unknown number of households of various European origins (26). The first 10 Japanese families settled the area in the early 1960s (27). Three major Japanese communities formed in the area based on the time period in which the immigrants arrived (26). Of the study area, 724 hectares are dedicated to agriculture. The location is suitable for floriculture and $60 \%$ of the Japanese households engage in this activity.

In Colonia Urquiza, the first HPS cases were confirmed in 1998, including one case (recovered) from the Japanese communities. The first Japanese victim of HPS was confirmed in the communities in 2002. The communities had the second victim of HPS in January 2007, while nine HPS cases (not including Japanese) occurred in Buenos Aires Province in December 2006 (25).

\section{Questionnaire design}

Review articles focusing on HPS were used to design the framework for the questionnaire $(1-4,8,28)$. HPS prevention materials designed by public health institutions for use at the household- and community-level were also consulted $(29,30)$. These were used in conjunction with the biological and epidemiological knowledge currently available to create questions. The questionnaire was de- 
signed for anonymous self-completion and organized into three sections: (1) household demographics, (2) HPS knowledge, and (3) HPS preventive measures in use. The questionnaire was written in English and then translated into Spanish and pre-tested, after which a small number of changes were made to improve clarity of questions.

Demographic data collected were as follows: selected characteristics for household head, household members, and the house itself, respectively. Responses to some demographic questions were designed to allow comparison with the results of a field study by other researchers in 2002 (27).

There were 10 questions regarding knowledge of hantavirus transmission and HPS treatment. A summary score was developed from these 10 questions, assigning one point for each correct response and zero for each incorrect or uncertain response. Another 10 basic questions were asked in order to identify HPS preventive techniques common among respondents.

\section{Questionnaire administration}

Questionnaires were distributed at the HPS prevention seminar sponsored by the Japanese Association at its meeting hall in Colonia Urquiza on 23 February 2007. Each head-of-household, or if absent, another household adult in attendance, received a questionnaire. In addition, prior to beginning the seminar, an oral presentation in Japanese, designed especially for the newest immigrants, explained the purpose of the questionnaire and asked each head-of-household to complete it. The time allotted to complete the questionnaire was 20 minutes. All the completed questionnaires were then collected by the staff of the association. Any duplicates-from the same household-were eliminated by face-toface assessment. Assistance was given to those who could not read the Spanish language questionnaire.

\section{Data analysis}

The data collected from the questionnaires were entered into a database using the OpenOffice.org 2.2 (Sun Microsystems, Santa Clara, California, United States of America). The statistical analyses were performed using the MCA package (31), Stata SE 9.2 (Stata Corpora- tion, College Station, Texas, United States). Maps were produced using the geographical information system software ArcGIS 9.0 (ESRI Incorporated, Redlands, California, United States).

Univariate and multivariate analyses were used to describe the differences between two household groups categorized according to the degree of HPS knowledge. Total HPS knowledge score dichotomized into high (equal to or more than the median knowledge score) and low (less than the median), and univariate analyses were conducted using Fisher's exact test for categorical variables, to identify the variables significantly associated with the HPS preventive measures in use.

Following the univariate analyses, an exploratory multivariate analysis was conducted using multiple correspondence analysis (MCA) to better understand the relationships among a set of categorical variables.

A disadvantage of the univariate analysis was that a set of variables, of which each is weakly associated with the outcome, can become important predictors when they are taken together. To prevent this, a significance level that was relatively safe $(P<0.45)$ was selected for MCA (32). One of the main objectives of correspondence analysis is to create a visual summary (two-dimensional) of the complicated associations that exist among a set of categorical variables (both predictors and the outcome). The two axes are factorial axes that indicate the most inertia (variability) in the original predictor variables. The result is a scatter-plot that determines clusters of closely-related predictors, with clusters farther from the intersection of the axes having stronger associations. The values of the outcome variable (also categorical) can also be projected on the same axes to identify which clusters of predictor variable values are associated with the outcomes of interest (33).

\section{RESULTS}

The 86 households that completed the questionnaire accounted for about $72 \%$ of the total Japanese households in the study area. The survey achieved 100\% participation among the households attending the seminar, according to the staff of Japanese Association in La Plata, which was charged with collecting the completed questionnaires.

The demographic characteristics of the study households are shown in Table 1 . The median number of household members and children was in broad agreement with the results of the field study mentioned above (three or four members, including one or two children in many families). Twelve percent of them responded that at least one family member had been diagnosed, clinically or serologically, with HPS during the preceding decade.

The percentage of the respondents' answers that reflected accurate HPS knowledge varied greatly between questions (Table 2). The percentage of questions that were answered correctly regarding the hantavirus-affected area, population at high risk, mortality, disinfection, and

TABLE 1. Demographic characteristics of study households $(n=86)$ in a cluster of Japanese communities in Argentina, 2007

\begin{tabular}{lc}
\hline \multicolumn{1}{c}{ Categories } & Values (range or percent) \\
\hline Gender of household head: male & $98 \%$ \\
Median age of household head & $52(29-76)$ \\
Median number of family members & $4(1-8)$ \\
Median number of adults ( $\geq 15$ years old) & $3(1-6)$ \\
Median number of children (<15 years old) & $0(0-4)$ \\
Number of generations living together in the home & One (32\%), two (40\%), three (28\%) \\
Median years since settling in the study area & $34(5-45)$ \\
Median number of hectares per household & $4(1-13)$ \\
Primary occupation of the family: agriculture & $88 \%$ \\
Primary language used at home: Japanese & $65 \%$ \\
Primary source of hantavirus knowledge & \\
person-to-person communication & $54 \%$ \\
Newspaper & $19 \%$ \\
Television & $14 \%$ \\
Government publicity & $9 \%$ \\
Radio & $2 \%$ \\
Magazine & $2 \%$ \\
\hline
\end{tabular}


TABLE 2. Percentage of the respondent's with accurate knowledge of hantavirus pulmonary syndrome (HPS) among a study sample of households $(n=86)$ in a cluster of Japanese communities in Argentina, 2007

\begin{tabular}{lr}
\hline \multicolumn{1}{c}{ Accurate knowledge } & $\%$ \\
\hline Hantavirus is not evenly distributed throughout Argentina & 7 \\
Ordinary disinfectants (not exclusively for the hantavirus) can kill the virus & 26 \\
One may be infected by the virus when bitten by a rat & 26 \\
Particular kinds of rats transmit the virus to humans & 81 \\
Mosquitoes do not transmit the virus to humans when sucking blood & 72 \\
Infected animals, other than rats, do not excrete the virus particles & 60 \\
Person-to-person transmission of the virus is not common & 84 \\
Workers in the field do not always have the virus infection & 14 \\
Those with HPS will not always die & 19 \\
We do not have a specific medicine for HPS & 67 \\
\hline
\end{tabular}

TABLE 3. Cross-tabulation of frequency-of-use of selected HPS preventive measures, grouped by knowledge scores, among a study sample of households $(n=86)$ in a cluster of Japanese communities in Argentina, 2007

\begin{tabular}{lcccr}
\hline \multicolumn{1}{c}{ Measures } & $\begin{array}{c}\text { High score } \\
\text { group }\end{array}$ & $\begin{array}{c}\text { Low score } \\
\text { group }\end{array}$ & \\
\cline { 5 - 5 } & $(\%, n=40)^{\mathrm{a}}$ & $(\%, n=46)^{\mathrm{b}}$ & $P^{\mathrm{c}}$ \\
\hline Promptly clean up the dining table after meals & 95 & & 93 & 1 \\
Properly dispose of leftover food & 95 & & 91 & 0.68 \\
Store animal feed in a container with a lid & 75 & & 48 & 0.01 \\
Wear rubber gloves when cleaning & 67 & & 35 & $<0.01$ \\
Use soap for washing hands after cleaning & 95 & & 89 & 0.44 \\
Have sealed piping holes at the base of the house & 65 & & 48 & 0.13 \\
Continuously use rat traps & 45 & & 17 & $<0.01$ \\
Clean garbage cans outside the house & 45 & & 48 & 0.83 \\
Do not accumulate any junk outside the house & 70 & 70 & 1 \\
Clean up the barbeque area after use & 85 & 74 & 0.29 \\
\hline
\end{tabular}

a High score group $=$ households with equal to or more than the median HPS knowledge score.

${ }^{b}$ Low score group $=$ households with less than the median HPS knowledge score.

c Fisher's exact test.

path of infection was relatively low $(<30 \%)$. The median knowledge score of 5 (range: $0-9$, of 10 ) divided the study households into two groups: highknowledge score group $(n=40)$ and lowknowledge score group $(n=46)$. Table 3 represents the relationship between selected HPS preventive measures and the knowledge score categories. The percentages for each preventive measure variable of the low-score group (range: 17-93) were more variable than those of the high-score group (range: 45-95). The low-score group had lower percentages for each preventive measure variable, except for one regarding the cleanliness of outdoor garbage cans (no statistical significance) compared to those of the high-score group.

Of the 10 preventive measures shown in Table 3, six variables were selected for MCA (Figure 2). The two dimensions presented in the plot explain $55 \%$ of inertia. The first dimension distinguishes between use of various preventive mea- sures, whereas the second separates according to the knowledge score category. Except for the preventive measure indicators "cleaning up the outdoor grill/barbeque" and "use of soap when washing hands," all the plots, including outcome variable points (knowledge score category), were clustered into two areas. On visual assessment in Figure 2, the cluster of the five variables coded 1 are more closely associated than the cluster of those coded 0 .

\section{DISCUSSION}

This survey represents a first attempt to understand perceptions regarding HPS knowledge and practices among a cluster of the rural Japanese communities in an epidemiologically high-risk area in Argentina. The fact that more than $70 \%$ of the study households attended the HPS prevention seminar reflects high public interest in the disease. The seminar sessions organized both in
Japanese and Spanish were well received by the first and younger generation settlers. More than half of the respondents had obtained hantavirus knowledge through face-to-face communication, although the information may not always have been accurately interpreted. This might be explained by the fact about two-thirds of the study households used Japanese at home as the primary language, while HPS information was being disseminated in Spanish by the mass media. Educational materials, especially for the first generation settlers, were needed. Consequently, an informative leaflet on HPS prevention was produced in Japanese in order to improve the HPS knowledge of inhabitants (Japanese Association in La Plata, 2007, unpublished).

It is clear that for community-based disease prevention programs to be successful in the short-term and sustainable in the long-term, inhabitants have to receive a perceived benefit from the program, one that does not necessarily have to be measurable on purely economic grounds $(8,12)$. Therefore, it is important to create a trusting relationship between the general public and officials. In the seminar sessions, municipal officials in charge of HPS management and prevention gave a lecture and emphasized strengthening collaboration with the Japanese communities.

The findings in Figure 2 in conjunction with Table 3 suggest an association between the knowledge background of individual households and their respective attitudes and the measures they take to prevent HPS. As the authors hypothesized, knowledge influences practices. The current study indicates a significant association between those who practice these preventive measures: (1) store animal feed properly, (2) use rubber gloves when cleaning, and (3) use rat traps, and the accurate knowledge that these are standard hygienic practices that reduce the risk of contracting hantavirus. In addition, it is notable that the main source of information was the person-to-person communication $(54 \%)$ and not the media or governmental publicity. These findings support the importance of media campaigns to implement educational and policy strategies.

Preventing exposure to rodents and their excreta lessens the risk of infection. Efforts should include the removal of rodent food sources from inside the home, measures to inhibit rodents access to the 
FIGURE 2. Two-dimensional plot based on Multiple Correspondence Analysis of indicators of a household's HPS preventive measures in use. Indicators of preventive measures (coded 0 for "no" or 1 for "yes") are displayed as column coordinates ${ }^{\text {a }}$ (Fisher's exact test, $P<0.05$ ); while the knowledge score category (coded 0 for less than the median score or 1 for equal to or more than the median) is added as supplementary column points

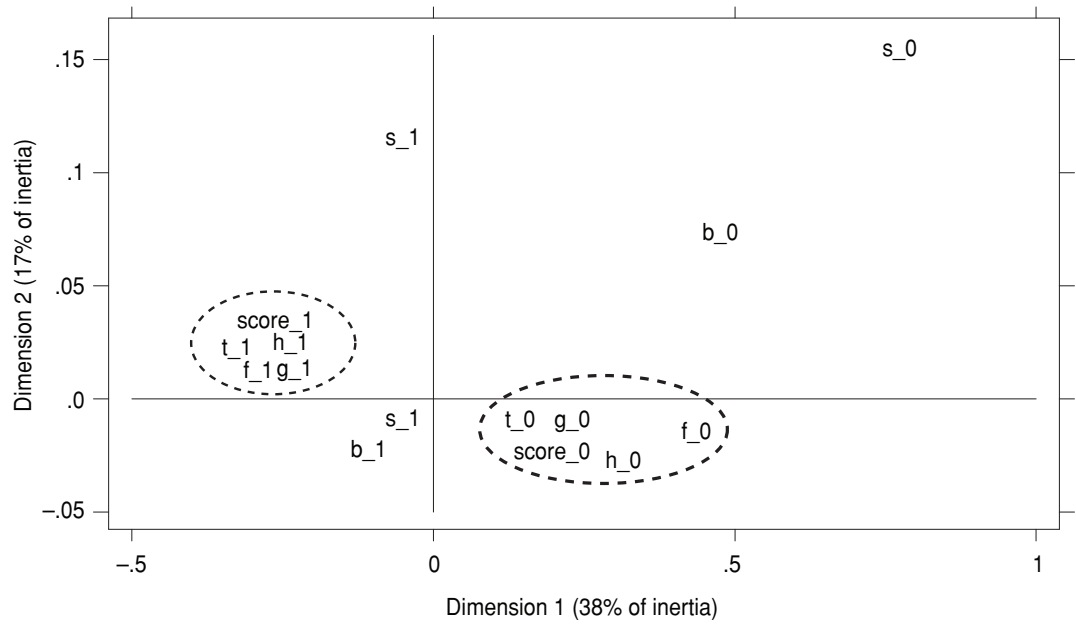

${ }^{a} \mathrm{~b}$ : Cleans up the outdoor grill after use; f: Stores animal feed in a container with a lid; g: Wears rubber gloves when cleaning; h: Sealed piping holes at the base of the house; s: Uses soap for washing hands after cleaning; t: Continuously uses rat traps.

home, and elimination of possible nesting sites and food sources from the area surrounding the home. When cleaning up areas that are possibly rodent-infested, proper safeguards should be taken (aeration of the room before entering, use of rubber gloves and disinfectant, avoidance of stirring up and inhaling dust). Rodents should be managed by traps; use of gloves and masks is recommended during manipulation of traps and carcasses (8). For a more general prevention of human infections, especially in risk groups such as the Japanese communities in the study area, the development of a hantavirus vaccine is necessary (1).

Climatic and other environmental factors may govern the population size and migration pattern of relevant hosts. It is essential to pay attention to the consequences of land use changes, especially those that increase human contact with potential reservoirs, such as rodents living in wetlands. In recent years, for example, there was an increase in the num- ber of sites near La Plata that were being used for soil extraction to support brick fabrication. These sites were then abandoned and converted into artificial wetlands with typical flora and fauna (34). The study communities have also expressed concerns over the municipal government's plans to build a city dump near the communities. A dump would likely become another breeding ground for rodents.

Another challenge lies in the fact that the reservoir of the two HPS-causing lineages of Andes virus in La Plata have not yet been identified (24). Detailed knowledge of rodent species distribution and their role as hantavirus reservoirs is needed.

When the potential respondents who were absent from the seminar were taken into account, it was apparent that the sample was not totally representative of the communities in general. The responses obtained are likely to represent inhabitants who are more motivated and interested in the topic. In addition, the questionnaire did not include questions regarding the educational level of respondents or their knowledge of warning signs and symptoms. This angle needs additional research. A lack of detailed demographics and HPS case statistics for the area, which is not a single administrative area, but rather straddles the border between districts, hampers the comparison of HPS cases among different ethnic groups (e.g., between those of Japanese descent vs. those of European descent).

Rodent control in and around the home remains the primary strategy for preventing hantavirus infection. From the public health point of view, the recommended measures that need to be used in concert are: (1) prevent rodents from entering the home by repairing gaps inside and outside the house, (2) trap rodents around the home to help reduce the population, (3) clean up rodent food sources and nesting sites, and (4) take precautions when cleaning rodent-infested areas. It is important to consider that dissemination and widespread adoption of preventive measures require education. Designing and implementing HPS educational programs and measuring their effectiveness should be priorities to incent the communities to take a more active role.

Acknowledgements. The study was carried out as part of the project for the capacity development for improvement of livestock hygiene in southern part of South America through regional cooperation (Proyecto de Desarrollo Profesional Continuo para los Veterinarios del SurPROVETSUR), funded by the Japan International Cooperation Agency. We wish to thank the staff of the Japanese Association (Asociación Japonesa La Plata) for their support. We are extremely grateful to the respondents who allowed us to work with them. Valuable and insightful comments by the reviewers and editor are gratefully acknowledged. We declare that we have no competing interests.

\section{REFERENCES}

1. Hart CA, Bennett M. Hantavirus infections: epidemiology and pathogenesis. Microbes Infec. 1999;1(14):1229-37.

2. McCaughey C, Hart CA. Hantaviruses. J Med Microbiol. 2000;49(7):587-99.

3. LeGuenno B. Hantaviruses. Med Maladies Infect. 1997;27(6-7):703-10.
4. Glass GE. Hantaviruses. Curr Opin Infect Dis. 1997;10(5):362-6.

5. Pini N. Hantavirus pulmonary syndrome in Latin America. Curr Opin Infect Dis. 2004; 17(5):427-31.

6. Della Valle MG, Edelstein A, Miguel S, Martinez V, Cortez J, Cacace ML, et al.
Andes virus associated with hantavirus pulmonary syndrome in northern Argentina and determination of the precise site of infection. Am J Trop Med Hyg. 2002;66(6): 713-20.

7. Lazaro ME, Resa AJ, Barclay CM, Calanni L, Samengo L, Martinez L, et al. Hantavirus 
pulmonary syndrome in Southern Argentina. Medicina-Buenos Aires. 2000;60(3):289-301.

8. Kruger DH, Ulrich R, Lundkvist A. Hantavirus infections and their prevention. Microbes Infect. 2001;3(13):1129-44.

9. Pan American Health Organization. Number of cases and deaths from Hantavirus Pulmonary Syndrome (HPS). Available from: http:/ / www.paho.org/English/AD/DPC/ CD/hantavirus-1993-2004.htm. Accessed 28 May 2007.

10. Chaparro J, Vega J, Terry W, Vera JL, Barra B, Meyer R, et al. Assessment of person-toperson transmission of hantavirus pulmonary syndrome in a Chilean hospital setting. J Hosp Infect. 1998;40(4):281-5.

11. Botros BA, Sobh M, Wierzba T, Arthur RR, Mohareb EW, Frenck R, et al. Prevalence of hantavirus antibody in patients with chronic renal disease in Egypt. T Roy Soc Trop Med H. 2004;98(6):331-6.

12. Coleman TJ. The Public Health Laboratory Service (PHLS) and its role in the control of zoonotic disease. Acta Trop. 2000;76(1):71-5.

13. Padula PJ, Edelstein A, Miguel SDL, Lopez NM, Rossi CM, Rabinovich RD. Hantavirus Pulmonary Syndrome outbreak in Argentina: molecular evidence for person-to-person transmission of Andes virus. Virology. 1998; 241(2):323-30.

14. Padula PJ, Colavecchia SB, Martinez VP, Della Valle MOG, Edelstein A, Miguel SDL, et al. Genetic diversity, distribution, and serological features of hantavirus infection in five countries in South America. J Clin Microbiol. 2000;38(8):3029-35.

15. Lopez N, Padula P, Rossi C, Lazaro ME, Franze Fernandez MT. Genetic identification of a new hantavirus causing severe pulmonary syndrome in Argentina. Virology. 1996; 220(1):223-6.

16. Lopez N, Padula P, Rossi C, Miguel S, Edelstein A, Ramirez E, et al. Genetic characterization and phylogeny of Andes virus and vari- ants from Argentina and Chile. Virus Res. 1997;50(1):77-84.

17. Levis S, Morzunov SP, Rowe JE, Enria D, Pini $\mathrm{N}$, Calderon $\mathrm{G}$, et al. Genetic diversity and epidemiology of hantaviruses in Argentina. J Infect Dis. 1998;177(3):529-38.

18. Levis S, Rowe JE, Morzunov S, Enria DA, St Jeor $S$. New hantaviruses causing hantavirus pulmonary syndrome in central Argentina. Lancet. 1997;349(9057):998-9.

19. Chomba EN, Haworth A, Atadzhanov M, Mbewe E, Birbeck GL. Zambian health care workers' knowledge, attitudes, beliefs, and practices regarding epilepsy. Epilepsy Behav. 2007;10(1):111-19.

20. Di Giuseppe G, Abbate R, Albano L, Marinelli $\mathrm{P}$, Angelillo I. A survey of knowledge, attitudes and practices towards avian influenza in an adult population of Italy. BMC Infect Dis. 2008;8(36):1471-2334.

21. Rahman M, Shimu TA, Fukui T, Shimbo T, Yamamoto W. Knowledge, attitudes, beliefs and practices about HIV/AIDS among the overseas job seekers in Bangladesh. Public Health. 1999;113(1):35-8

22. Gobierno Municipal de La Plata. Portal La Plata. Available from: http://www.laplata. gov.ar/. Accessed 28 May 2007.

23. Sosa-Estani S, Martinez VP, Della Valle MG, Edelstein A, Miguel S, Padula PJ, et al. Hantavirus in human and rodent populations in an endemic area for hantavirus pulmonary syndrome in Argentina. Medicina-Buenos Aires. 2002;62(1):1-8.

24. Martinez VP, Colavecchia S, Alay MG, Suzuki B, Trincheri A, Busto S, et al. Hantavirus pulmonary syndrome in Buenos Aires Province. Medicina-Buenos Aires. 2001;61(2):147-56

25. ProMED. Hantavirus, casos: actualización Argentina (B. Aires). Available from: http:/ / www.promedmail.org/pls/otn/f?p=2400:12 02:895485712891574::NO::F2400_P1202_CHE CK_DISPLAY,F2400_P1202_PUB_MAIL_ID: X,35693. Accessed 28 May 2007.
26. Federación de Asociaciones Nikkei en la Argentina. Historia del inmigrante japonés en la Argentina: período de posguerra (versión en japonés). Buenos Aires: FANA; 2006.

27. Cafiero II, Cereno E. Una mirada a la inmigracion japonesa en la Argentina: el caso de la Colonia General Justo Jose de Urquiza en el Partido de La Plata (Provincia de Buenos Aires), formas de adaptacion de los Issei y Nikkei. In: Aramburo JR, (ed). XI Congreso Internacional de Asociacion Latinoamericana de Estudios de Asia y África; Mexico city: 2003.

28. Butler JC, Peters CJ. Hantaviruses and Hantavirus Pulmonary Syndrome. Clin Infect Dis 1994;19(3):387-94.

29. United States Centers for Disease Control and Prevention. All about Hantaviruses. Available from: http:/ / www.cdc.gov/ncidod/diseases/ hanta/hps/index.htm. Accessed 28 May 2007.

30. Pan American Health Organization. Hantavirus. Available from: http://www.paho. org/English/AD/DPC/CD/hantavirus.htm. Accessed 28 May 2007.

31. Van Kerm P. MCA: stata module to perform multiple correspondence analysis. Available from: http:/ /ideas.repec.org/c/boc/bocode/ s335503.html. Accessed 28 May 2007.

32. Noordhuizen JPTM, Frankena K, Thrusfield MV, Graat EAM. Application of quantitative methods in veterinary epidemiology. 2nd ed. Wageningen: Wageningen Pers; 2001.

33. Greenacre MJ. Correspondence analysis in practice. London: Academic Press; 1993.

34. JJ, De Francesco FO, Colado UR, Novoa ML, Schnack EJ. Humedales antropicos: su contribucion para la conservacion de la biodiversidad en los dominios subtropical y pampasico de la Argentina. Ecol Austral. 2000; 10:63-80.

Manuscript received on 28 October 2007. Revised version accepted for publication on 14 July 2008.

RESUMEN Objetivos. Documentar los conocimientos y las prácticas relacionadas con el síndrome pulmonar por hantavirus (SPH) en un conglomerado de comunidades rurales japonesas cerca de La Plata, en la parte central de Argentina, una zona con casos confirmados de SPH. Se hizo hincapié especial en probar la hipótesis de que habría diferencias en el empleo de medidas preventivas contra el $\mathrm{SPH}$ en los hogares según el nivel de conocimientos del jefe de familia sobre este síndrome.

Métodos. Se diseñó un cuestionario con tres secciones: a) características demográficas del núcleo familiar, b) conocimientos sobre el SPH y c) medidas preventivas contra el $\mathrm{SPH}$. Los cuestionarios se aplicaron a los jefes de familia o a algún adulto que representara al núcleo familiar durante un seminario sobre prevención del SPH patrocinado por la Asociación Japonesa de La Plata en febrero de 2007. El conocimiento sobre el SPH se clasificó según su puntuación total en alto (igual o mayor que la mediana de las puntuaciones) y bajo (menor que la mediana). Se analizaron las diferencias entre los dos grupos según el grado de conocimientos sobre el SPH.

Resultados. Respondieron representantes de 86 hogares, aproximadamente $72 \%$ del total de la zona. La mediana de la puntuación fue de 5 (entre 0 y 9 en una escala de 10) y permitió clasificar los hogares en dos grupos: 40 tenían un nivel de conocimientos alto y 46, bajo. Los resultados indicaron una asociación entre los conocimientos correctos sobre el SPH en un hogar y el empleo de medidas preventivas contra el SPH en ese hogar.

Conclusiones. Estos resultados tienen implicaciones importantes para emprender acciones dirigidas a mejorar el control y la prevención del SPH.

Palabras clave Síndrome pulmonar por hantavirus, roedores, etnia y salud, Argentina. 